Diabetologia 10, $485-487(1974)$

(C) by Springer-Verlag 1974

\title{
The Treatment of Lactic Acidosis in the Diabetic Patient by Peritoneal Dialysis Using Sodium Acetate. A Report of Two Cases
}

\author{
J.C. Hayat \\ Department of Internal Medicine and Nephrology, Hôpital Ambroise Paré, Boulogne, France \\ Received: December 27, 1973, and in revised form: April 22, 1974
}

\begin{abstract}
Summary. Lactic acidosis is a rare but serious complication of the use of biguanides in anti-diabetic therapy. This report details two cases of diabetic lactic acidosis secondary to Metformin, successfully treated by peritoneal dialysis, using sodium acetate as the dialyzing substance. The author emphasizes the use of extra-renal purification, and more specifically peritoneal dialysis, as symptomatic
\end{abstract}

\begin{abstract}
therapy of lactic acidosis in the diabetic patient. Acetate, rather than lactate, as the dialyzing substance, is most justified from a biochemical point of view.
\end{abstract}

Key words: Lactic acidosis, diabetes, extra-renal purification.
The serious prognosis associated with lactic acidosis in diabetic patients has been the motivation in the search for factors favouring its appearance and for effective therapeutic measures when it occurs $[1,2]$. This report details two cases of diabetic lactic acidosis successfully treated by peritoneal dialysis, using sodium acetate as the dialyzing substance.

\section{Case-Report}

\section{Case 1}

Mr S, 74 years old, was known to be diabetic for about twenty years and was stabilized on Metformin (dimethylbiguanide) one gram per day. $\mathrm{He}$ was noticed to have moderate hypertension (160/100 $\mathrm{mmHg}$ ) and renal insufficiency, with a creatinine clearance of $30 \mathrm{ml} / \mathrm{min}$. He was hospitalized because of a recent change in his general state of health. Laboratory studies showed neither alteration of renal function nor signs of plasma electrolyte or acid-base disorders and an intravenous pyelogram was performed. After this, oliguria, without abdominal pain or distended bladder, occurred. The patient's diuresis was only $100 \mathrm{ml}$ per $24 \mathrm{~h}$ despite $160 \mathrm{mg}$ of Furosemide. The next day, the patient was still oliguric, with clouding of consciousness, vomiting and tachypnoea. The study of blood electrolytes revealed severe acidosis with a $\mathrm{pH}$ of 6.9 , blood bicarbonate content of $8 \mathrm{mEq} / \mathrm{l}$, hyperkalaemia with $6.8 \mathrm{mEq} / \mathrm{l}$, and a rise in the non-protein serum nitrogen level to $170 \mathrm{mg} / 100 \mathrm{ml}$. The blood glucose was $138 \mathrm{mg} / 100 \mathrm{ml}$, the total serum protein $15.6 \mathrm{mEq} / \mathrm{l}$, serum chlorides $108 \mathrm{mEq} / \mathrm{l}$ and serum sodium 124 $\mathrm{mEq} / \mathrm{l}$. This combination of acute renal failure with severe acidosis and hyperkalemia prompted us to begin peritoneal dialysis (glucose $83 \mathrm{mOsm} / 1$, sodium lactate $45 \mathrm{mEq} / \mathrm{l}$ ). After several hours, the level of blood bicarbonate was still low $(17 \mathrm{mEq} / \mathrm{l})$ and that of lactic acid (which attained before the beginning of the peritoneal dialysis $6.5 \mathrm{mEq} / \mathrm{l})$ still high $(6 \mathrm{mEq} / \mathrm{l}$; normal $=1 \mathrm{mEq} / \mathrm{l})$. We therefore replaced the peritoneal dialysis fluid by one containing $35 \mathrm{mEq} / \mathrm{l}$ of sodium acetate, with spectacular clinical im. provement within eight hours. Biologically, the improvement was slower: after $12 \mathrm{~h}$ of dialysis, the $\mathrm{pH}$ was still 7.34, the blood bicarbonate $21 \mathrm{mEq} / \mathrm{l}$, the serum potassium $5.6 \mathrm{mEq} / \mathrm{l}$, and the serum lactate $2 \mathrm{mEq} / \mathrm{l}$. The next day, the improvement continued. After $400 \mathrm{mg}$ of Furosemide, urine production started once again: $800 \mathrm{ml}$ of urine containing $118 \mathrm{mEq} / \mathrm{l}$ of sodium, $107 \mathrm{mEq} / 1$ chlorides, and $18 \mathrm{mEq} / \mathrm{l}$ of potassium. There was loss of weight equal to $400 \mathrm{~g}$. At the end of $36 \mathrm{~h}$ of dialysis, serum non protein nitrogen was $110 \mathrm{mg} / 100 \mathrm{ml}$, $\mathrm{pH} 7.44$, serum bicarbonates $24 \mathrm{mEq} / \mathrm{l}$, serum potassium $4.2 \mathrm{mEq} / \mathrm{l}$ and serum lactate $1.2 \mathrm{mEq} / 1$. The restoration of renal function was confirmed by a urine output greater than $2500 \mathrm{ml} / 24 \mathrm{~h}$.

\section{Case 2}

Mrs F., 56 years old, a diabetic for 10 years, was treated with Metformin (1.5 g per day). She had already been hospitalized six months earlier for upper gastro-intestinal haemorrhage and alcoholic cirrhosis was diagnosed. She presented with headache, vomiting and fever, then progressively sank into coma. Examination showed a comatose patient with bilateral mydriasis, absent left achilles reflex and a Babinski reflex on the left side (flexion on the right side). Excessive bronchial secretions, with cyanosis, required tracheal intubation and periodic bronchial suction. The cardio-vascular examination was normal, the blood pressure was $140 / 70 \mathrm{mmHg}$, and the ECG normal. Upon her arrival in the Department, examination of her urine showed: glucose $1+$, ketones $2+$. The first blood investigations showed: blood glucose $400 \mathrm{mg} / 100 \mathrm{ml}$, severe metabolic acidosis with a $\mathrm{pH}$ at 7.20 , blood bicarbonate content $10 \mathrm{mEq} / \mathrm{l}$, and an anionic gap of $40 \mathrm{mEq} / \mathrm{l}$. (Table 1). The serum 
potassium was $3 \mathrm{mEq} / \mathrm{l}$, serum sodium $143 \mathrm{mEq} / \mathrm{l}$, serum chlorides $96 \mathrm{mEq} / 1$ and blood ketones 0 . There was a moderate hypercapnia with a $\mathrm{PaCO}_{2}$ of $56 \mathrm{mmHg}$ We suspected lactic acidosis and decided on massive alkalinization as a first step. In two hours the patient received 11 of sodium bicarbonate, containing $42 \mathrm{~g} / \mathrm{l}$, and $500 \mathrm{ml}$ of sodium bicarbonate containing $14 \mathrm{~g} / \mathrm{l}$. The urinary output was $900 \mathrm{ml}$ in $2 \mathrm{~h}$, glycosuria $5+$, ketonuria $3+$, blood lactic acid level $9 \mathrm{mEq} / \mathrm{l}$. We decided to artificially ventilate the patient, to administer massive doses of intravenous and subcutaneous insulin, to pursue her rehydration by hypotonic dextrose solution and saline, and her

Table 1. Lactic acidosis in a diabetic patient treated by $1.5 \mathrm{~g}$ of Metformin (case 2). Course during the first three days: with massive alkalinization and sodium acetate peritoneal dialysis, correction of acid-base balance and decrease in serum lactate level. Alveolar hypoventilation with moderate hypoxia due to alkalinization

\begin{tabular}{llll}
\hline & Day 1 & Day 2 & Day 3 \\
\hline $\mathrm{SaO}_{2} \%$ & 98 & 98 & 98 \\
$\mathrm{PaO}_{2} \mathrm{mmHg}$ & 85 & 60 & 65 \\
$\mathrm{PaCO}_{2} \mathrm{mmHG}$ & $\mathbf{5 6}$ & $\mathbf{3 4}$ & 26 \\
$\mathrm{pH}$ & 7.20 & 7.52 & 7.58 \\
$\mathrm{CO}_{3} \mathrm{H}^{-} \mathrm{mEq} / 1$ & $\mathbf{1 0}$ & $\mathbf{2 6 . 5}$ & 26 \\
Serum lactate & $\mathbf{9}$ to 17 & 0.4 & - \\
mEq/1 & & & \\
\hline
\end{tabular}

\begin{tabular}{|c|c|c|c|}
\hline Therapy & & & \\
\hline $\begin{array}{l}\text { Bicarbonate } \\
\text { mEq }\end{array}$ & 400 & 100 & 0 \\
\hline $\begin{array}{l}\text { Peritoneal } \\
\text { dialysis } \\
\text { (Sodium Acetate } \\
35 \mathrm{mEq} / \mathbf{l} \text { ) }\end{array}$ & Begining & Continued & End \\
\hline Insulin I.U & 300 & 200 & 150 \\
\hline
\end{tabular}

alkalinization by isotonic bicarbonate. Four hours later, in spite of the alkalinization, the lactic acid blood level remained at $17 \mathrm{mEq} / \mathrm{l}$. We therefore decided to undertake sodium acetate peritoneal dialysis $(35 \mathrm{mEq} / \mathrm{l})$ while continuing insulin therapy. Twelve hours later, the blood glucose level remained high at $450 \mathrm{mg} / 100 \mathrm{ml}$ with $3+$ glycosuria, and $2+$ ketonuria. However, the acid-base balance had been corrected: there was a respiratory alkalosis with a $\mathrm{pH}$ of 7.52 and the blood bicarbonate level of 26.5 $\mathrm{mEq} / \mathrm{l}$. The serum sodium was $135 \mathrm{mEq} / \mathrm{l}$, serum potassium $3.5 \mathrm{mEq} / \mathrm{l}$ and serum lactic acid level $0.4 \mathrm{mEq} / 1$ (Table 1). Assisted ventilation, peritoneal dialysis, and insulin therapy (delayed action insulin) were continued; glucose input was reduced. During the following days, the biochemical improvement continued. Clinically, after a phase of hypotonicity, which was more marked on the right side, we observed a progressive regression of the coma with reaction to pinching, then response to incitement. On the fifth day, the dialysis was stopped, and the insulin therapy reduced. The patient was extubated, and oral feeding was started on the 8th day. On the 15 th day, there was no longer any problem of re-equilibration. Biopsy of the liver revealed stigmata of cirrhosis, but the renal function was strictly normal. An E.E.G. was performed one month after the coma and showed an irregular tracing with several rhythmic posterior theta waves, without significant asymmetry. The study of the arterial blood gases at rest showed alveolar hyperventilation, with a pH of 7.53 and hypocapnia $\left(\mathrm{PaCO}_{2}\right.$ of $24 \mathrm{mmHg}$ ). The $\mathrm{PaO}_{2}$ did not exceed $430 \mathrm{mmHg}$ during $20 \mathrm{~min}$ administration of pure oxygen.

\section{Discussion}

I) Etiology. It is necessary to point out that these two patients were long-standing diabetic patients treated by Metformin [4, 6]. Two circumstances favouring lactic acidosis appearance were found; in case 1 , this was acute kidney failure, which occurred after the injection of radio-opaque dye for pyelography. Renal failure appears to be an etiological factor favouring the occurrence of lactic acidosis in a diabetic patient undergoing biguanide treatment. These medications are predominantly eliminated by the kidney, and it is probable that transitory renal failure can result in the elevation of their plasma concentration to toxic levels. In case 2 , the presence of cirrhosis constituted the predisposing cause; and hepatic failure, either acute or chronic, always increases an already elevated lactate level, whatever its origin, because lactate metabolism is essentially hepatic [10].

II) Biochemical Parameters. We observed severe metabolic acidosis with a $\mathrm{pH}$ near 7 , blood bicarbonate level of $10 \mathrm{mEq} / \mathrm{l}$ or less, and an alveolar hyperventilation with hypocapnia. The serum potassium was elevated in case 1 , but this was especially related to the concurrent renal failure; the serum potassium was normal, then decreased in case 2 and this was related to the evolution of the diabetic keto-acidosis. The anion gap was $40 \mathrm{mEq} / \mathrm{l}$ in case 2 ; the existence of ketones probably constituted a part of this anion gap. The serum lactate, measured by the enzymatic method, was elevated in repeated measurements, reaching a maximum of $6.5 \mathrm{mEq} / 1$ in case 1 and $17 \mathrm{mEq} / 1$ in case 2 [9].

III) Therapy. The treatment of lactic acidosis, in the absence of a medication which will diminish the overproduction of lactate or facilitate its reutilization by the liver, limits us to symptomatic therapy [3]. The massive administration of alkali (about $500 \mathrm{mEq}$ in case 2), which must always be carried out, is inefficient in compensating the constant production of free $\mathrm{H}+$ radicals and only permits a very modest correction of the plasma bicarbonate. Peritoneal dialysis using $45 \mathrm{mEq} / \mathrm{l}$ sodium lactate (in case 1) was equally inefficient in re-establishing acid-base equilibrium [1]. Extra-renal purification, however, permits the removal of lactate (at the rate of 1450 $\mathrm{mEq} / 24 \mathrm{~h}$ for a peritoneal dialysis) and the use of $\mathrm{t}$ 
dialyzing liquid without lactate is justified [8]. Among the dialyzing liquids without lactate, a case can be made for acetate, as it has been proven to be useful to use the salt of an organic anion to treat acidotic patients if the anion is readily metabolized, and this seems to hold true for acetate during lactic acidosis [7]. The use of a dialyzing liquid containing bicarbonate is conceivable, but is not desirable from a practical point of view. The elevation of bicarbonate concentration in the extra-cellular fluid and of $\mathrm{H}_{2} \mathrm{CO}_{3}$ in the lungs produces respiratory and metabolic alkalosis [5].

\section{Conclusion}

Extra-renal purification using a salt of an organic anion like acetate seems the best symptomatic treatment of lactic acidosis, especially in the diabetic patient. By its efficiency, it permits the removal of lactate and the rapid restitution of acid-base balance.

\section{References}

1. Auzepy, Ph., Masliah, R., Planchon, R., Baulon, A., Lemonier, A., Deparis, M. : Acidose lactique. Importance pronostique du diagnostic precoce. Ann. méd. int. 122, 13-20 (1971)
2. Assan, R.: Acidose lactique. Colloques de Réanimation de l'Hopital Claude Bernard, Arnette Ed., 1971

3. Attali, J.R.: Contribution à l'étude de l'acidose lactique. I-Analyse physio-pathologique de l'acidose lactique humaine, 2-Etude experimentale du traitement des acidoses lactiques par la dialyse peritoneale chez le rat blanc. Paris: These 1971

4. Azerad, E., Lubetzki, J., Duprey, J., Friedler, D. L'acidose lactique chez les diabetiques. A propos de 7 observations. Presse méd. 77, 1705-1708 (1969)

5. Boen, S.T.: Peritoneal dialysis in clinical medicine. In: Kugelmass (ed.). Springfield, IIl.: Thomas Publisher 1964

6. Mac Gregor, G.A., Boodle-Wilson, P.A., Jones, N.F.: Phenformin and metabolic acidosis. Lancet 1972 I $69-71$

7. Henderson, A.R.: Biochemistry of hypoxia: Current concepts. Brit. J. Anaesth. 41, 245-250 (1969)

8. Jurgesen, J.C.: Dialysis for lactic acidosis. New Engl. J. Med. 278, 1350 (1968)

9. Oliva, P. B.: Lactic acidosis. Amer. J. Med. 48, 209$225(1970)$

10. Tranquada, R.E.: Lactic acidosis. Calif. Med. 101, $450-455$ (1964)

J.C. Hayat, M.D.

Hôpital Ambroise Paré

Dept. of Internal Medicine and

Nephrology

9 Av. Ch. de Gaulle

F-92100 Boulogne

France 